\title{
Paideusis
}

\section{Philosophy of Education: Introductory readings (4th ed.; William Hare and John P. Portelli (Eds.))}

\section{David P. Burns}

Volume 22, Number 1, 2014

Sexual and Gender Diversity in Schools

URI: https://id.erudit.org/iderudit/1071472ar

DOI: https://doi.org/10.7202/1071472ar

See table of contents

Publisher(s)

Canadian Philosophy of Education Society

ISSN

0838-4517 (print)

1916-0348 (digital)

Explore this journal

Cite this review

Burns, D. (2014). Review of [Philosophy of Education: Introductory readings (4th ed.; William Hare and John P. Portelli (Eds.))]. Paideusis, 22(1), 118-119.

https://doi.org/10.7202/1071472ar viewed online.

https://apropos.erudit.org/en/users/policy-on-use/ 
Paideusis, Volume 22 (2014), No. 1, pp. 118-119

Review of

\title{
Philosophy of education: Introductory readings (4th ed.)
}

by William Hare and John P. Portelli (Eds.), Edmonton, AB: Brush Education, 2013

\author{
DAVID P. BURNS \\ Kwantlen Polytechnic University
}

About one year ago I began writing the curriculum for a new philosophy of education course. It had to be appropriate for persons looking to pursue K-12 teacher education (the traditional subject of philosophy of education) elsewhere, but also for persons looking to educate younger children, college and university students, or even adults in workplace environments. My teaching in conventional BEd programs at other universities prepared me, as one might expect, for only one part of this task. I thus called out for help and soon received a sizeable pile of recently published survey texts on the philosophy of education. Thus was an enjoyable, if somewhat dry, holiday season spent. While I cannot claim to have read each of these texts in the detail each deserves, I have paid close attention to several of the choices each author had to make. Is an anthology or a single authored text best? Should one begin with today's pedagogical problems, or Plato? Should one proceed by topic, or by time? The answer, according to my thoroughly informal review, is that there is a wide range of both anthological and single-authored texts, but that they nearly always begin with the classics and proceed via a mixture of chronological and topical progression. Curren (2007), for example, begins with Plato in the first section and ends with contemporary curricular controversies in the last section reaching back in time to Locke and Rousseau when particular issues arise. Noddings (2012) begins with Socrates and Plato and winds her way to contemporary feminism and care theory. Ozmon (2012) starts with idealism (under which he includes Plato and Kant) and closes with postmodernism. Gutek (2009), after a brief introduction, moves similarly from Plato to globalization. By the time I was asked to review Philosophy of education: Introductory readings (Hare \& Portelli, 2013), I had more or less internalized this organizational structure.

The contrast between that conventional structure and Hare \& Portelli's collection immediately stood out. The first sentence of the introduction makes clear that the target audience of the text is pre-service teachers, and this intention is manifested throughout the text in a number of thoughtful ways. While each of the texts I note above is a helpful scholarly offering (Curren and Noddings offer especially strong texts), Hare \& Portelli's work is, I think, the strongest instance of a book designed to draw people in to philosophy of education. It does two things particularly well, I think. First, as I note above, it structures its analysis around the questions on the minds of undergraduate students and instructors of philosophy of education (rather than with the intellectual history or foundation of philosophy of education). The foundational or historical approach is certainly helpful, but I have found this route far more productive for graduate students than undergraduate students. Second, this collection provides a strong Canadian perspective without being unduly parochial. I will briefly address these strengths in turn and will then address a somewhat narcissistic misgiving.

Each time I have taught philosophy of education - be it to pre-service teachers or liberal arts students I have struggled to convey the richness of the field in a way that is accessible. I very much want them to read Plato, Kant, and Rousseau. However, I must have given my students a sense of the value of this form of

(C) Copyright 2014. The author, David P. Burns, assigns to Paideusis the right of first publication and educational and non-profit institutions a non-exclusive license to use this document for personal use and in courses of instruction provided that the article is used in full and this copyright statement is reproduced. Any other usage is probibited without the express permission of the author. 
thought before such difficult and sometimes distant texts can be savoured. This is why I was quite pleased to see that Hare \& Portelli open with articles on the theory-practice divide, the role of empirical research, the nature of human agency, and the place of ideals in teaching. Confusion about the basic nature of "theory," "practice," and "research" has held back a great many of my students, and addressing the varied conflations and ambiguities these words often occasion is a pressing challenge in my classes. It is only after such clarification that I think it is possible to understand how powerful and stimulating a close reading of Plato can be for a prospective educator. Section 2 (on controversial curricular issues) makes a similarly direct and meaningful contribution to my future classes. It isn't difficult to imagine that, after considering sections 1 and 2, many students will be well positioned to understand the relevance and power of this field. The book arguably loses some of this focus in the following section on democracy, but section 5 (on the balance of rights and freedoms in the classroom) is very strong indeed.

The second core strength of this book is that it balances the strongest Canadian scholarship in this area with important scholarship from outside of Canada. Paideusis itself is, for example, represented through a number of reprinted articles. Indeed, one finds in this book a strong collection of the most established Canadian philosophers of education, including Heesoon Bai, Robin Barrow, Michelle Forrest, William Hare, Dwight Boyd and others. There is also space in this volume for those who have come to prominence in the field since the previous edition's publication in 2001, including Claudia Ruitenberg, Andrea English and Trevor Norris (whose 2011 book on consumerism and schools is very much worth reading). Frances Kroeker and Steven Norris have an excellent entry in the text, and I was quite happily introduced to the work of Dianne Gereluk, whose analysis of Alberta's famous Bill 44 is one of the best I have encountered. Having recognized many of the strongest scholars in Canada's philosophy of education community, Hare and Portelli also include a number of key thinkers from abroad. David Hansen, Harvey Siegel and Gert Biesta are all well selected inclusions. The articles selected for this volume are, in short, quite deserving of their place.

An anthology of this sort is difficult to pull together, however, and will always be vulnerable to the critiques of specialists in particular areas - each convinced of the merit of including her own foci. It might be fair to say, however, that environmental education is the most important emerging issue philosophers of education will be grappling with in the next few years. Helping students to come to understand what environmental lessons should be taught, for instance, is crucially important and distinctly philosophical, and it seems to me clear that future educators will deal with increasingly difficult environmental philosophical questions. This book will help those educators indirectly (Bai's entry, for instance, is of indirect assistance in this regard), but not in the direct and contextual sense that is required.

In sum, aside from the perennial critique to be made of all anthologies, Hare \& Portelli provide an outstanding offering. The section introductions are well done, but the articles fit together so well (particularly in the first couple of sections) that one doesn't necessarily require them to understand the flow of the text. If you are looking for a graduate-level text, you might choose Curren (2007). If you want an undergraduate text, but don't want an anthology, Noddings (2012) is a good candidate. Hare \& Portelli (2013) is the strongest undergraduate anthology with which I am familiar.

\section{References}

Curren, R. (Ed.). (2007). Philosophy of education: An anthology. Malden, MA: Blackwell.

Gutek, G. L. (2009). New perspectives on philosophy and education. Columbus, OH: Merrill.

Hare, W., \& Portelli, J. P. (Eds.). (2013). Philosophy of education: Introductory readings (4th ed.). Edmonton, AB: Brush Education.

Noddings, N. (2012). Philosophy of education (3rd ed.). Boulder, CO: Westview Press.

Norris, T. (2011). Consuming schools: Commercialism and the end of politics. Toronto, ON: University of Toronto Press.

Ozmon, H. A. (2012). Philosophical foundations of education (9th ed.). Upper Saddle River, NJ: Pearson. 